\title{
Application of the novel and convenient IR/MAR gene amplification technology to the production of recombinant protein pharmaceuticals
}

\author{
Yoshio Araki ${ }^{1}$, Chiemi Noguchi', Tetsuro Hamafuji ${ }^{2}$, Hiroshi Nose² ${ }^{2}$ Daisuke Miki ${ }^{3}$, Noriaki Shimizu ${ }^{*}$ \\ From 22nd European Society for Animal Cell Technology (ESACT) Meeting on Cell Based Technologies \\ Vienna, Austria. 15-18 May 2011
}

Amplification of DHFR gene in $\mathrm{CHO}$ cells by selection of MTx has been widely applied to the establishment of stable cell lines that efficiently produce recombinant protein pharmaceuticals. However, the DHFR/MTx technology was highly time-and labor-consuming. On the other hand, we had found that a plasmid bearing a mammalian replication initiation region (IR) and a matrix attachment region (MAR) initiates gene amplification in mammalian cells, and it quite efficiently generate the chromosomal HSR and/or the extrachromosomal DMs $[1,2]$. This is a completely original technology of gene amplification, and we have revealed the mechanism why and how such plasmid may mimic gene amplification $[2,3]$. Now, we aimed to adopt this technology to the industrial production of recombinant protein pharmaceuticals.

We constructed plasmids with or without IR/MAR, with several promoters for drug resistant gene, antibody gene or Fc receptor gene, and with various orientations of these elements. The plasmid DNA with several physical structures were transfected to human COLO 320DM or hamster CHO DG44 cells, with or without another DNA. The transformed cells were selected by various conditions. The polyclonal transformants or the cloned cells were evaluated by the protein production (ELISA), as well as by the structure of amplified region (FISH).

As a result, the usage of IR/MAR technology enabled us to obtain cells, in which the introduced genes were amplified to a few hundreds to thousands copies per cells as DMs or HSR of various size and shape (Figure 1 ), which depended both on the vector constructs and the host cell lines. Such stable cells with amplified genes could be obtained within one month, and the protein production was increased more than a hundred-fold compared with the case without IR/MAR. A cell clone showed the specific production rate that reached almost the highest reported for antibody protein $(45 \mathrm{pg} / \mathrm{cell} /$ day). Furthermore, we have found several novel ways that further improve the protein production level. For example, the combination of the IR/MAR and the DHFR/MTx technologies synergistically work and far more rapidly and easily generate the cells of higher production rate than previously.

In conclusion, the IR/MAR technology is a novel highly-competitive technology for use in recombinant protein production, and it further has potentials for improvement.

\section{Author details}

${ }^{1}$ Graduate School of Biosphere Science, Hiroshima University, Higashihiroshima, 739-8521, Japan. ${ }^{2}$ Transgenic Inc., Kobe, 650-0047, Japan. ${ }^{3}$ Tosoh Co., Tokyo, 252-1123, Japan.

Published: 22 November 2011

\section{References}

1. Shimizu N, Miura Y, Sakamoto Y, Tsutsui K: Plasmids with a Mammalian Replication Origin and a Matrix Attachment Region Initiate the Event Similar to Gene Amplification. Cancer Res 2001, 61:6987-6990.

2. Shimizu N, Hashizume T, Shingaki K, Kawamoto J: Amplification of plasmids containing a mammalian replication initiation region is mediated by controllable conflict between replication and transcription. Cancer Res 2003, 63:5281-5290.

3. Harada S, Sekiguchi N, Shimizu N: Amplification of a plasmid bearing a mammalian replication initiation region in chromosomal and extrachromosomal contexts. Nuc Acids Res 2011, 39:958-969.

\footnotetext{
*Correspondence: shimizu@hiroshima-u.ac.jp

${ }^{1}$ Graduate School of Biosphere Science, Hiroshima University, Higashi-

hiroshima, 739-8521, Japan

Full list of author information is available at the end of the article
}

(c) 2011 Araki et al; licensee BioMed Central Ltd. This is an open access article distributed under the terms of the Creative Commons Attribution License (http://creativecommons.org/licenses/by/2.0), which permits unrestricted use, distribution, and reproduction in any medium, provided the original work is properly cited. 


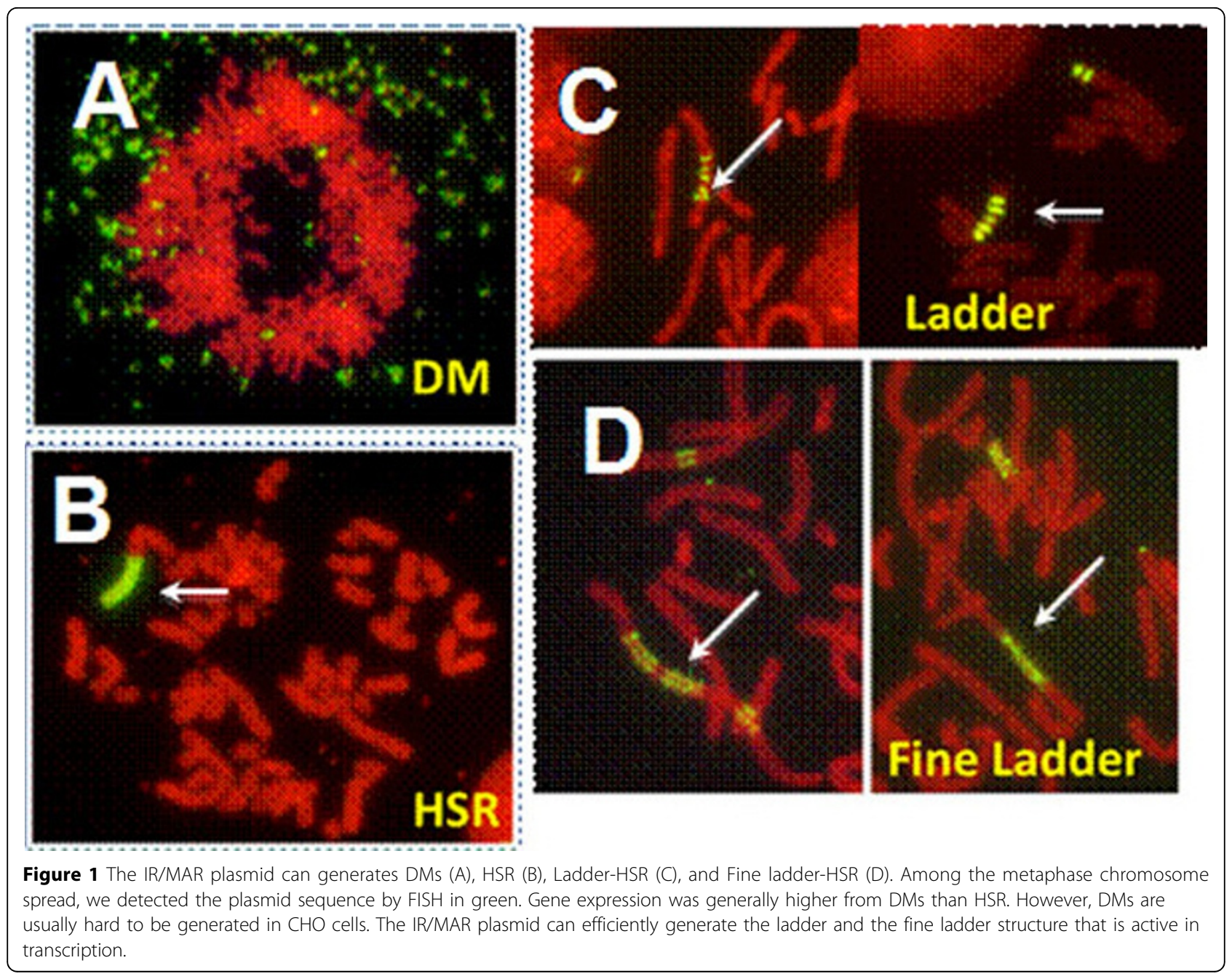

doi:10.1186/1753-6561-5-S8-P131

Cite this article as: Araki et al:: Application of the novel and convenient IR/MAR gene amplification technology to the production of

recombinant protein pharmaceuticals. BMC Proceedings 2011 5(Suppl 8):

P131.

\section{Submit your next manuscript to BioMed Central} and take full advantage of:

- Convenient online submission

- Thorough peer review

- No space constraints or color figure charges

- Immediate publication on acceptance

- Inclusion in PubMed, CAS, Scopus and Google Scholar

- Research which is freely available for redistribution 